\title{
Effect of MST on Crystallinity of CST/Sludge Glasses
}

by

M. K. Andrews

Westinghouse Savannah River Company

Savannah River Site

Aiken, South Carolina 29808

P. J. Workman

D. M. Marsh

DOE Contract No. DE-AC09-96SR18500

This paper was prepared in connection with work done under the above contract number with the $U$. S.

Department of Energy. By acceptance of this paper, the publisher and/or recipient acknowledges the U.S.

Government's right to retain a nonexclusive, royalty-free license in and to any copyright covering this paper, along with the right to reproduce and to authorize others to reproduce all or part of the copyrighted paper. 


\section{DISCLAIMER}

This report was prepared as an account of work sponsored by an agency of the United States Government. Neither the United States Government nor any agency thereof, nor any of their employees, makes any warranty, express or implied, or assumes any legal liability or responsibility for the accuracy, completeness, or usefulness of any information, apparatus, product, or process disclosed, or represents that its use would not infringe privately owned rights. Reference herein to any specific commercial product, process, or service by trade name, trademark, manufacturer, or otherwise does not necessarily constitute or imply its endorsement, recommendation, or favoring by the United States Government or any agency thereof. The views and opinions of authors expressed herein do not necessarily state or reflect those of the United States Government or any agency thereof.

This report has been reproduced directly from the best available copy.

Available to DOE and DOE contractors from the Office of Scientific and Technical Information, P. O. Box 62, Oak Ridge, TN 37831; prices available from (423) 576-8401.

Available to the public from the National Technical Information Service, U. S. Department of Commerce, 5285 Port Royal Road, Springfield, VA 22161. 


\section{DISCLAIMER}

Portions of this document may be illegible in electronic image products. Images are produced from the best available original document. 

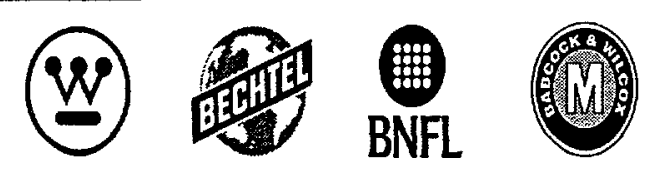

WSRC-RP-98-01131

September 28, 1998

\title{
EFFECT OF MST ON CRYSTALLINITY OF CST/SLUDGE GLASSES (U)
}

\author{
M. K. Andrews, P. J. Workman and D. M. Marsh \\ Westinghouse Savannah River Company
}

Aiken, S. C. 29808

\section{Introduction}

In support of the Salt Disposition team, the effects of monosodium titanate (MST) on two glass formulations were investigated. These glass formulations combined a blend-type sludge with Crystalline Silicotitanate (CST) and glass formers (or frit). The objective of the testing was to determine if the MST would lead to crystal formation in the glasses.

\section{Experimental Method}

Six glasses containing MST, CST, sludge and two different frit compositions (Frit 1 and Frit 2) were vitrified in platinum crucibles at $1150^{\circ} \mathrm{C}$. Table 1 lists the concentrations that were used for each frit composition. After melting for four hours, the glasses were heat treated at $1000^{\circ} \mathrm{C}$ for 24 hours. In addition, baseline glasses without MST were vitrified and heat treated. The samples were then submitted to the Analytical Development Section (ADS) for quantitative analysis by X-Ray Diffraction (XRD).

Table 1 - Frit, Sludge, CST and MST Concentrations Tested

\begin{tabular}{|l|c|c|c|}
\hline & \multicolumn{3}{|c|}{ wt\% } \\
\hline & Column A & Column B & Column C \\
\hline Frit 1 and 2 & 68.5 & 63.5 & 68 \\
\hline Sludge & 26 & 26 & 26 \\
\hline CST & 5.0 & 10 & 5.0 \\
\hline MST & 0.5 & 0.5 & 1.0 \\
\hline
\end{tabular}




\section{Results}

The baseline (without MST) compositions had the same concentrations of sludge and CST. The frit (or glass formers) concentration was increased to compensate for the lack of MST. Columns A and C had identical baseline compositions since each contained the same concentrations of CST and sludge. If the liquidus temperature of the glass was above $1000^{\circ} \mathrm{C}$, then crystals would be expected in the glass after heat treating at $1000^{\circ} \mathrm{C}$ for 24 hours.

All of the samples were submitted to ADS for XRD analysis. The results indicated that all of the glasses were amorphous (no crystals were present). Therefore, the liquidus temperature of these glasses would be expected to be below $1000^{\circ} \mathrm{C}$. The results of this testing only apply to the two tested glass formulations. If a different frit composition is selected, additional testing with MST will be necessary.

\section{Conclusions}

MST (up to $1 \mathrm{wt} \%$ in the glass) does not appear to affect the crystallization of the sludge/CST glasses, even after heat treatment. Glasses with and without MST (at CST loadings of 5 or $10 \mathrm{wt} \%$, and waste loadings of $26 \mathrm{wt} \%$ sludge oxides) were amorphous after heat treatment of $1000^{\circ} \mathrm{C}$ for 24 hours. This indicates that amorphous glasses can be produced when the DWPF limit of $1 \mathrm{wt} \% \mathrm{TiO}_{2}$ is exceeded.

\section{Approvals}

$\frac{G \text { Ghu KNarlom for EWH }}{\text { E. W. Holtzscheiter }} \quad 10-2-98$

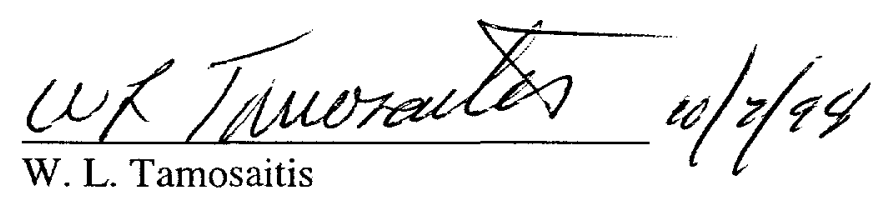




\section{Distribution}

M. K. Andrews, 773-A

S. B. Beck, 704-1T

N. E. Bibler, 773-A

J. T. Carter, 704-3N

D. A. Crowley, 773-43A

H. H. Elder, 704-S

S. A. Fink, 773-A

C. R. Goetzman, 773-A

J. R. Harbour, 773-43A

E. W. Holtzscheiter, 773-A

R. A. Jacobs, 704-T

L. F. Landon, 704-1T

S. L. Marra, 704-25S

D. M. Marsh, 773-A

J. F. Ortaldo, 704-S

L. M. Papouchado, 773-A

C. T. Randall, 704-T

K. J. Rueter, 704-3N

W. L. Tamosaitis, 773-A

P. J. Workman, 773-A

STI (4 copies), 703-43A 